Vector Analysis. By C. Runge. Vol. I. Translated by H. Levy. New York, Dutton and Co., 1923. vi + 226 pages.

This translation contains the vectors of three-dimensional space. The original was reviewed in this BuLletin, vol. 27, ser. 2, p. 464. There is little to add with regard to the translation. Heavy black letters have been substituted for German letters, which is more in conformity with prevailing customs, and tends to legibility, and the pages have been printed in a more open manner. The book is printed on thick paper which is a disadvantage as it makes it somewhat clumsy to use, and is not likely to be durable. The reviewer wonders why the translator saw fit (p. 211) to use cogradience and contragradience instead of the common terms cogrediency and contragrediency. The book will be of little use to students of physics particularly.

\title{
J. B. SHAW
}

Champ de Gravitation d'une Sphère Matérielle et Signification Physique de la Formule de Schwarzschild. By Jean Becquerel. Paris, J. Hermann, 1923. $32 \mathrm{pp}$.

La Théorie Einsteinienne de la Gravitation. By Gustave Mie (translated by J. Rossignol). Paris, J. Hermann, 1922. xi $+118 \mathrm{pp}$.

The first of these publications contains an interesting interpretation of Schwarzschild's equation by means of an orthogonal projection of the non-euclidean solar field upon an asymptotic Minkowskian plane four-space tangent to the solar field at infinity.

This problem is also treated in an appendix which lends distinction to an otherwise undistinguished pamphlet by Mie.

\section{N. ReYNolds, JR.}

Annuaire pour l'An 1923. Publié par le Bureau des Longitudes. Paris, Gauthier-Villars, 1923. 654 pp. + Appendices.

Only minor changes are noticeable in the Annuaire for 1923, although these are all of a nature to keep the publication up to date. Since the volume no longer appears well in advance of the year of date, astronomical information for the succeeding year is given in a supplement.

Besides two "Notices", one by P. Appell on Gabriel Lippmann and the other by A. Jobin on Jules Carpentier, a long one entitled Le climat de France: l'eau atmosphérique is contributed by G. Bigourdan. This gives in readable form the main features of what we call weather and climate with the physical principles which are to be used in the discussion of them. Particular attention is paid to rainfall, its distribution in time and space, with tables for various departments of France.

E. W. Brown 